\title{
Reconciliation in Critical Times: A Critical Discourse Analysis of Obama' Speech in Cairo University and Sadat's Speech in Knesset
}

\author{
Lecturer: Mohammed Nasser Abdulsada \\ Dept. of English, Wasit \\ University/mohmednasser@rocketmail.com
}

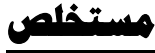

يتتاول هذا البحث المصالحة من خلال تجسيد الذات والآخر في خطاب اوباما وخطاب السادات وذلك في اطار تحليلي نقدي. و المصالحة هي تحييد الصراعات أو الحروب أو النزاعات السابقة بين الدول أو الأطراف من أجل الوصول الى اتفاقات أو تنازلات تصب في مصلحة الطرفين وفي هذا السياق يتناول البحث نموذجين للمصالحة: الأول هو خطاب الرئيس المصري السادات عند زيارته لإسرائيل والثاني هو خطاب الرئيس الأميركي بار الك أوباما في جامعة القاهرة عند زيارته لمصر. أراد السادات الوصول الى صلح مع إسر ائيل بعد حرب عام سلو I بين مصر وبعض الدول العربية من جهة و إسر ائيل من جهة أخرى أما أوباما فقد أراد أن يبدأ صفحة جديدة مع العالم العربي ودول المنطقة بعد فترة من الركود شهدت الكثير من تضارب المصالح و استخدام القوة. استخدم الباحث تجسيد الذات والآخر في تحليل خطاب الرئيسين إن تجسيد الذات والآخر هو الصورة الذهنية المتشكلة عند طرفي نزاع أو صر اع أو حرب نتيجة لانعكاس أو نمط معين. يعرض البحث في البداية مدخل الى ماهية البحث ومجاله ومن ثم يتناول المصالحة باعتبار ها توسط أو توافق بين طرفين متنازعين وبعد ذللك يستعرض البحث التحليل النقدي الخاص بصورة الذات والآخر وأثر هذا التجسيد على اتمام المصالحة. فضلاً عن ذللك، يعرض البحث بعض الدراسات السابقة التي تناولت المصالحة في الخطاب السياسي وفي السياق السياسي. كلمات دلالية: المصالحة، تجسيد الذات والآخر، التحليل النقدي للخطاب، اوباما، السادات، الخطاب السياسي.
\end{abstract}

Abstract

Reconciliation is a softening of past conflicts. This paper investigates reconciliation as it was implicated in the speeches of two presidents in two different times and situations. Anwar El Sadat gave a speech in the Knesset in Jerusalem addressing the Israeli people shortly after the 1973 war and Barack Obama gave a speech in Cairo in 2009 following the toppling of the former Egyptian president in the large-scale popular uprising by the people. Obama wanted to re-establish a new relation between USA and the Arab/Muslim world as the said relation has been overwhelmed by tremendous and various circumstances and conditions, including geopolitical interests, differences, acts of war, and the like. Sadat addressed the Israelis in the Knesset following a fierce war between Egypt and other Arab countries on one side and Israel on the other side. He desired to launch a new relation with the everlasting enemy in the region. The two speeches are critically investigated through self-other presentation approach to highlight the stances, attitudes, intentions, and desires of either party to reach reconciliation. Firstly, reconciliation is elaborated on. Secondly, self-other presentation is introduced with a brief discussion on the significance of critical discourse analysis and political discourse. Thirdly, an analysis of the two speeches is conducted. Finally, the paper presents some findings or results, conclusions, as well as further areas of areas.

Key Words: Reconciliation, Obama, Sadat, Critical discourse analysis, Self-Other presentation,

\section{Introduction}

Political Discourse, Political Speech

In 1776, Edward Burke, a member of the British parliament, gave a speech in the British parliament, in which he summed to his fellow members, his view towards Britain's stance of the American colonies. Though Burke's plan was rejected, the prospects of peace and reconciliation went far than expected. The acts of war ended in 1776 and this was followed by the Declaration of Independence. Similarly, in the second half of the 1980s, the former Soviet leader Mikhael Gorbachev made attempts to reconcile with Japan. Russia and Japan had disagreements over different 
economic and territorial issues that lasted unresolved as early as the 1950s. He, however, failed and may be this is attributed to the little efforts he made. Hi (2009:46) argues that, during the early years of Communist rule, in the 1950s, Chinese ruling elites sought to de-emphasize Japanese war crimes in order to improve bilateral relations. The ultimate goal was to counteract American influence in the region through Japan's recognition of the Communist regime. By attributing Japanese war crimes to a small number of military officers, Chinese elites were able to mount to people's diplomacy where both the Chinese and ordinary Japanese citizens were victims of Japanese militarism. Hi (2009:57) maintains that "Chinese elites' views of Japanese militarism converged with that of Japan's conservative leadership, who were anxious to assign wartime behavior to a few."

In 2009 in Cairo University, the American president Barack Obama (henceforth, Obama) addressed the Muslim nations in order to launch reconciliation with Muslims and Arabs. Though there has been much criticism and controversy over Obama's speech, it however had its own significance. Obama wanted to turn a new page with the Arab and Muslim world following the well-known policies taken by the previous American administrations towards this area in general and towards its crises and issues in particular. On the other hand, as late as the mid-1970s, the Egyptian president Anwar El Sadat (henceforth, Sadat) gave a speech in the Israeli Knesset following the 1973 war between Israel and some Arab nations, including Egypt. Both presidents gave speeches during critical and controversial moments in the course of their own respective audiences.

This study sheds light on political reconciliation as a means of mediation between disagreed or different parties by comparing the reconciliatory discourse in the speeches of two presidents. Both speeches will be critically tackled using van Dijk's (2001) self-other presentation.

\section{Reconciliation}

In its most general sense, reconciliation refers to a condition of nonviolent, mutually acceptable coexistence where former enemies come to re-envision one another as fellow citizens. Murphy (2010:8) states "political reconciliation broadly refers to the process of rebuilding political relationships. It will spell out what transformed and rebuilt decent relationships are like. It will also clarify what a process must do if it is to be effective, namely, rebuild political relationships in the requisite ways".

Reconciliation debates often center on the appropriateness of trials, truth commissions, lustration, official apologies, memorials, reparations, amnesties, and other institutions and policies to address the past. Where violence was between countries (such as between Japan and the Koreas), reconciliation normally refers to reestablishing social, political, and economic relations among erstwhile adversaries (Abdel-Noor, 2013:30). On occasion, it is misleading to speak of reconciliation, since there is no prior morally acceptable condition to which to return (indeed, South Africa is illustrative - it is hardly the case that relations between white colonists and black Africans were ever particularly just), but the term continues to be used to deal with post-violence relations. 
Reconciliation is defined as the re-establishment of friendly or cordial relations between two or more parties, usually following a certain conflict, struggle or war. It aims at the neutralization of any previous or past disagreements or discords. $\operatorname{MWCD}^{[1]}$ (2004:1040) defined reconciliation as "the act of causing two people or groups to become friendly again after an argument or disagreement."

\section{Review of Related Literature}

Studies concerned with reconciliation often focused on the political aspects of reconciliation or the sort of reconciliation achieved following wars, crises, or struggles. Burnet (2008) explored the role of Gacaca process in Rwanda as a committee dedicated to interview the victims of war in Rwanda (1997-2002) and to establish reconciliation. The author found that there has been much variation in the work of this committee across Rwanda and that this committee has not made sufficient efforts to reach the truth about the genocide in Rwanda. This process, rather, sought to fulfill certain goals and aimed only to reach reconciliation with the victims of the genocide. The author also concluded that the local circles of justice have acted unfair with respect to the people responsible for war crimes.

Škerlep (2009) investigated the rhetoric of reconciliation during the most intense transition processes in Slovenia by drawing on a rhetorical criticism of the Slovenian president's Milan Kuäœan's speech in 1990. The transition process had to recognize some events that happened in Slovenia at the end of the Second World War. The families of those soldiers, along with their sympathizers, claimed recognition of these executions during the transition period. The achievement of president's reconciliatory rhetoric in 1990 is that his masterful rhetorical speech recognized the suppressed minority.

Aguado (2012) studied the transition in Spain in the social, political and economic aspects following the end of the Franco dictatorship. He found that the Spanish society encountered a difficulty in coexistence with the previous as well as the current situation, for there had been many obstacles in the path of reconciliation with the past. Politicians involved found that people did not accept easily to reconcile with the former regime, even though many promises were given by the next government to reach the truth.

Basic (2012) investigated the narratives of the survivors of the BosniaHerzegovina war in 1990s with reconciliation, where he interviewed some survivors of this war and studied their style and rhetoric. He found that some of those offenders or the responsible for the acts of war showed an emotional remorse and regret having been involved, and thus they sought reconciliation with the survivors and the families of the victims.

Popovska and Ristoska (2012) studied reconciliation in Macedonia following the separation from Yugoslavia and the consequent conflicts that happened afterward. They found that the issues of multiculturalism, multi-ethnicity and multilingualism caused a great division in the country. Citizens were unable to bridge the multiple differences they encountered, in addition to identity being the main concern in politics and policy making in resolving such issues through the culture of dialogue between Albanians and Macedonians to reach an acceptable reconciliation. 
Albanians and Macedonians had to reach reconciliation through a full understanding of the folklore and cultural history of each other.

Surenthiraraj (2013) studied speeches given by the Sri Lankan president, Mahinda Rajapaksa, from 2008 to 2012 on the ethnic conflict in Sri Lanka and it aimed at reconciliation. He discussed presidential discourse produced by Sri Lankan President Mahinda Rajapaksa in six speeches across the years 2008 to 2012. It examined the speaker's discourse during the latter stages and following the Sri Lankan ethnic conflict to determine the positioning of major social actors in the conflict in relation to firstly, how the President positioned social actors towards himself and each other, and secondly, the storylines he issued to support these positions. Additionally, the paper also inquired if there was a shift in the positioning adopted during post-war speeches which would signal a shift from war schema into reconciliation schema.

\section{Methodology and Research Technique}

The approach followed in this research is Critical Discourse Analysis (CDA). CDA is an approach to the study of discourse. It considers language as a practice of communication where there is an emphasis on the ways social and political domination operate in text and talk. (Fairclough, 1989: 5) maintained that " "Critical" is used in the special sense of aiming to show up connections which may be hidden from people such as the connections between language, power, and ideology."

\section{Self-Other Presentation}

Self-Other Presentation is a strategical framework that helps justify the presentation or formation of our things versus their things, or self versus other. van Dijk (2000) introduced a framework for such strategies that involves:

- Emphasize positive things about Us

- Emphasize negative things about Them

- De-emphasize negative positive things about Us

- De-emphasize positive things about Them.

The aspects mentioned above comprise the so-called 'ideological square' (van Dijk, 2000:44). van Dijk (2004:260) adds that, following these strategies, neutral topics about Us are preferable, whereas negative topics are neglected, which is obvious in the lexical aspects about Other. Since ideologies are constructed and produced by discourse, this has to take place through certain structures and forms. For example, the pronouns We and They are used to refer to the in-group of the speaker and the out-group of the addressee. These areas of presentation are introduced or formulated through certain levels of speech, including accusation, defense, detailing, explicitness, implicitness, negative words about Other, positive words about Self, and active and passive sentences.

\section{Study Sample and Data Source}

The sample of the study includes two speeches for analysis. The first one is a speech given by Barack Obama in Cairo University and the second one is a speech given by Anwar El Sadat in the Knesset. Obama's speech script is taken from the White House website https://www.whitehouse.gov/the-press-office/remarks- 
president-cairo-university-6-04-09. Sadat's speech script in Arabic is taken from http://www.knesset.gov.il, while the English translation of that speech is taken from http://www.zionism-israel.com.

\section{Obama's Speech in Cairo University}

In April 2009, Obama gave a speech in Cairo University where he addressed the Muslims and Arabs alike. It was the first time ever an American president addressing Muslims and Arabs and in their native home, taking into account the different attitudes and stances assumed by the former American administrations as well as presidents towards the issues of this region. His goal was to reconcile with Muslims and Arabs following years of controversy and disagreement between the two parties.

"Good afternoon. I am honored to be in the timeless city of Cairo and to be be hosted by two remarkable institutions. For over a thousand years, Al-Azhar has stood as a beacon of Islamic learning. And for over a century, Cairo University has been a source of Egypt's advancement. Together, you represent the harmony between tradition and progress. I 'm grateful for your hospitability and the hospitability of the people of Egypt. And I'm also proud to carry with me the good will of the American People and a greeting of peace from Muslim communities in my country:

Assalamu-alaikum."

Obama started his speech with a greeting "Good afternoon" but following praising the host, he switched to their native greeting "Assalamu-alaikum." The audience appreciated such move and it has been seen as a shift from self to the other. At the beginning, Obama emphasizes the Self by using "I" and "American people", then he moved to the Other by using "Assalamu-alaikum." Regarding politeness, Obama acknowledges for having been hosted by "the hospitability of the people of Egypt." He, then, praises Cairo as a "timeless city" having "remarkable institutions", "Al-Azhar as a beacon of Islamic learning" and "Cairo University, a source of Egypt's advancement." This corresponds with Brown and Levinson's (1987) view of politeness through the demonstration of face-wants and the approval of the other.

Right from the beginning, Obama states expressly the aim of his visit, which is "to carry the good will of the American people" and later on he stated "this cycle of suspicion and discord must end " which is as an obligation on the part of the Self towards the Other.

These excerpts of Obama's speech carry more than one implication. Firstly, Obama uses obligation to highlight an obligation on the part of the Self, as stated previously. Secondly, Obama expressed a clear and vivid desire for sharing between the Self and the Other when he says "our progress must be shared." Hence, here, the Self is mediating the distance with the other. Thirdly, this attempt proves that Self is not only approaching to the Other, but also wishes to begin reconciliation by using common pronouns "our." Obama moves further in shifting from Self to Other and eventually to common grounds rather than separate or different parties. The 
following excerpt, for example, shows such shift. He does not talk about two different entities. Rather, he focuses on the aspects that imply sharing, cooperation and mutuality.

"I've come to Cairo to seek a new beginning between the United States and Muslims around the world, one based on mutual interest and mutual respect, and one based upon the truth that America and Islam are not exclusive and need not to be in competition. Instead, they overlap and share common principles, principles of justice and progress, tolerance and the dignity of all human beings."

Again, Obama highlights commonness as a positive aspect suggested by the Self to eliminate and remove any previous disagreements.

The principle of sharing, which Obama stresses, is based on the inclusion of both the Self and the Other as one thing. Thus, he uses all, us, share, common and our. This is also justifies the repetition made several times of sharing and to share. Obama repeatedly stresses the significance of sharing, especially in terms of pronominal use, as a way to the reconciliation of previous misunderstandings:

"This is what I will try to do today, to speak the truth as best as I can. Humbled

by the task before us and firm in my belief that the interests we share as human

beings are far more powerful than the forces that drive us apart."

Obama uses the collective pronouns $u s$ and we to identify himself as in-group member. Therefore, he can claim common or shared interests or predict future actions or plans: the task before us, the interests we share, and the forces that drive us apart. Significantly, Obama switches to $I$ but he still keeps inclusiveness with the Other:

"I'm Christian. But my father came from a Kenyan family that includes generations of Muslims. As a boy, I spent several years in Indonesia and heard the call of the azaan at the break of the town and at the fall of the dusk. As a young man, I worked in Chicago communities where many have dignity and peace in their Muslim faith."

Obama, then, moves to the Other to maximize and demonstrate the role of the Other:

"I also know civilization's debt to Islam. It was Islam in places like Al-Azhar that carried the light of learning through so many centuries, paving the way for Europe's renaissance and enlightenment. It was innovation in Muslim communities....... It was innovation in Muslim communities that developed the order of algebra, our magnetic compass and tools of navigation, our mastery of pens and printing, our understanding of how disease spreads and how it can be healed. Islamic culture has given us majestic arches and soaring spires, timeless poetry and cherished music, elegant calligraphy and places of 
peaceful contemplation. And throughout history, Islam has demonstrated through words and deeds the possibilities of religious tolerance and racial equality. I also know that Islam has always been a part of America's story. The first nation to recognize my country was Morocco."

Acknowledging debt to the Other proves to be effective, especially when it comes to reconciliation. Obama keeps counting the debts of the Other (Islam or Muslims) to the Self (America). On the other hand, the Other (the audience) receives well such applause and praise in favor of them. Not only this, Obama also says that:

"The same Holy Quran that one of our founding fathers, Thomas Jefferson, kept

in his personal library."

Though in terms of our actions and their actions, Obama's statements pose the Self in a seemingly weak position, he, later on, maximizes the importance of the Self by elaborating on America' global role:

"The United States has been one of the greatest sources of progress that the world has ever known."

He also counts certain merits to the Self:

"Nearly seven million American Muslims in our country today, who, by the way, enjoy incomes and educational levels that are higher than the American average. Moreover, freedom in America is indivisible from the freedom to practice one's religion. That is why there is a mosque in every state in our union and over 1,200 mosques within our borders."

The other strategy, that is effective in reconciliation, is the admission of guilt and repentance, which is the core of Brown and Levinson's negative politeness strategy. The said strategy is indirect and hence it is seen as a mitigated form. This is obvious in Obama's statement:

"The fear and anger that it [9/11] provoked was understandable. But, in some cases, it led us to act contrary to our traditions and our ideals. We are taking concrete actions to change course."

By saying so, Obama presupposes that there are some reasons or motivations that led to the current state of things between the Self (America) and the Other (Muslims). In other words, Obama does not wish to expressly state such reasons whether the reasons of 9/11 attacks in America or the actions taken by America against the countries presumably behind these attacks. In terms of reconciliation, Obama expresses disapproval of the actions of both parties.

Obama also elaborates on the situation in Iraq, where he implicitly and indirectly disapproves the American policy in Iraq following the 2003-war:

"Unlike Afghanistan, Iraq was a war of choice that provoked strong differences in my country and around the world. Although I believe that the Iraqi people 
are better off without the tyranny of Saddam Hussein, I also believe that events in Iraq have reminded America of the need to use diplomacy and build international consensus to resolve our problems whenever possible."

When Obama mentions diplomacy, he means that other choices could have been made instead of war, which is indirect presupposition on the part of the Self and is suggestive of deficiency. America could have used diplomacy as well as international consensus to shift the course of actions in Iraq rather than military force or action.

Obama comes much closer to reconciliation by the polite promises he makes to the Other:

"We would gladly bring every single one of our troops home if we could be confident that there not violent extremists in Afghanistan."

Since reconciliation entails certain promises and compromises, the assertives and declarations stated by the Self to the Other are in the interest of the Other:

"I have made it clear to the Iraqi people that we pursue no basis and no claim on their territory or resources."

Shortly before the end of the speech, Obama reverses to the inclusive we to share the common interests between the Self and the Other:

"We have a responsibility to join together on the behalf of the world that we seek. Those are mutual interests. That is the world we seek. But, we can achieve it together. If we choose to be bound by the past, we will never move forward."

Interestingly, Obama quotes the Holy Quran to extend reconciliation and pushes the Other to a common ground:

"The Holy Quran tells $u s$, Mankind, we have created you male and a female.

And we have made you into nations and tribes so that you may know one another."

Obama also quotes a piece of the Holy Bible, namely the Talmud, to maintain commonness and togetherness which he seeks:

"The people of the world can live together in peace. We know that is God's vision. Now that must be our work here on Earth.

Thank you. And may God's peace be upon you. Thank you very much. Thank you."

\section{Sadat's Speech in Knesset ${ }^{[2]}$}

On November 20, 1977, the then-Egyptian president Anwar El Sadat (Hence, Sadat), paid a visit to Jerusalem, Israel, a visit that had caused much shock and controversy across the Arab and Muslim world. Though Sadat's visit to Israel had multiple political and social effects on not only the Arab world, but also on Egypt, as well as on Sadat himself, having been pressured by the other Arab nations, yet 
this visit had other implications. Linguistically, the visit was a significant event as Sadat gave a speech in the Knesset that is immemorial.

Sadat visited Israel for peace and reconciliation with a country that has been in war with Egypt as early as the mid-1950s. In terms of structure, Sadat began his speech with his own greeting (the Self): السـام عليكم [Peace be upon you]. Sadat also states the reasons of his visit:

$$
\text { "وقد جئت اليكم اليوم على قدمين ثابتتين لكي نبني حياة جديدة لكي نقيم السلام" }
$$

"I come to you today on solid ground to shape a new life and to establish peace"

Sadat at the beginning puts the Self جئت, then he shifts to the Other اليكم, and then he refers to both the Self and the Other as one inclusive entity:

$$
\text { لكي نبني حياة جديدة، لكي نقيم السلام }
$$

The tone of reconciliation in Sadat's speech is obvious. Sadat emphasizes his desire for this visit:

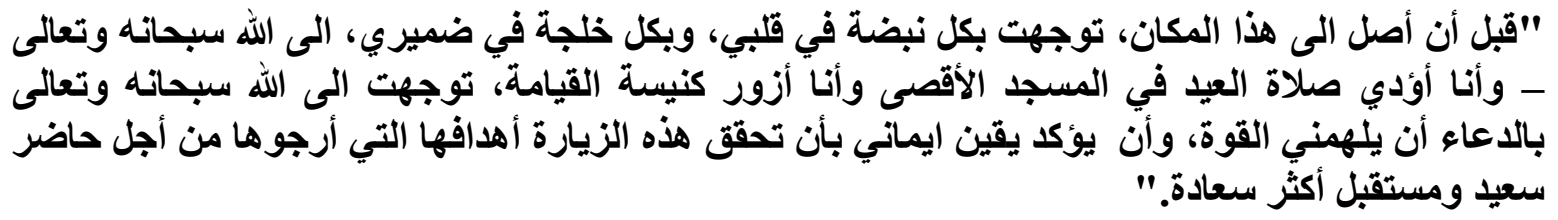

"Before I came to this place, with every beat of my heart and with every sentiment, I prayed to God Almighty, while performing the Corban Bairam prayers, and while visiting the Holy Sepulcher, to give me strength and to confirm my belief that this visit may achieve the objectives I look forward to, for a happy present and a happier future"

Sadat resorts to common interests found between the Self (Sadat, Egypt) and the Other (Israel) in order to maintain commonness and togetherness:

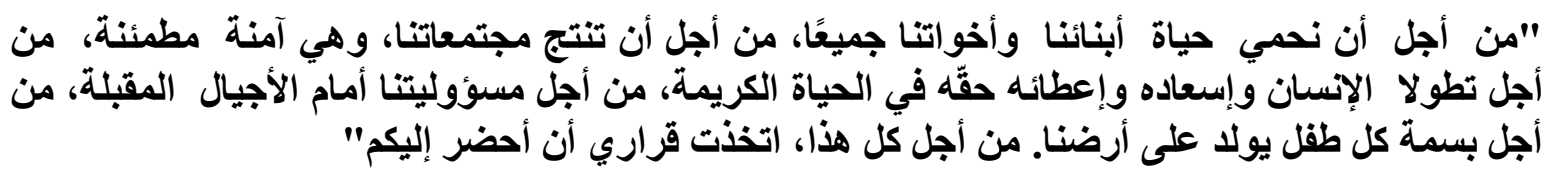

"For the sake of the lives of all our sons and brothers, for the sake of affording our communities the opportunity to work for the progress and happiness of man, feeling

secure and with the right to a dignified life, for the generations to come, for a smile

on the face of every child born in our land, for all that I have taken my decision to come to you"

Sadat also states some origins, mainly religious ones, which the Self and the Other have in common:

$$
\text { "ابراهيم -عليه السلام- جد العرب واليهود " }
$$

"Abraham-peace be upon him-great-the grandfather of Arabs and Jews"

Notwithstanding, Sadat blames Israel, and hence he takes a negative face toward the Other, as in:

$$
\text { أنتم تحتلون أرضا عربية بالقوة المسلحة. }
$$

"You are occupying Arab territories by force of arms"

And in: 
"وجلتم المبرر، القانوني والأخلاقي، لأقامة وطن قومي على أرض، لم تكن كلها ملكا لكم"

"You have found the moral and legal justification to set up a national home on a land that did not all belong to you"

Sadat goes further than that and imposes obligation on the Other and therefore making a self-praise:

$$
\text { "عليكم أن تواجهوا الواقع مواجهة شجاعة، كما واجهته أنا" }
$$

"You have to face reality bravely, as I have done"

And:

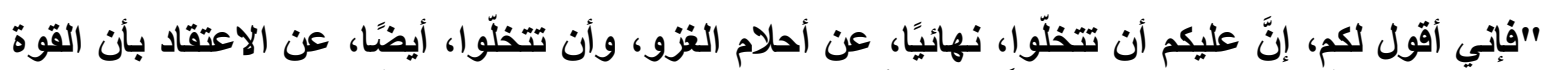

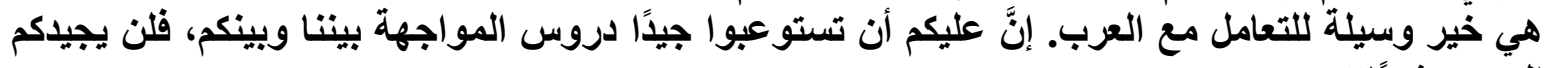
التوسع شيئًا

"I am telling you. You have to give up once and for all the dreams of conquest and give up the belief that force is the best method for dealing with the Arabs. You should also understand the lessons of confrontation between us. Expansion does not pay"

Sadat uses a negative face with the Other by assuming warning and threatening and by dictating conditions and actions:

$$
\text { "أرجوا أيضا أن أحذركم، بكل صدق، أحذركم من بعض الخواطر التي يمكن أن تطرأ على أذهانكم" }
$$

"I would also wish to warn you, in all sincerity, I warn you, against some thoughts that could cross your minds"

\section{Discussion and Comparison}

Concerning the aspects of reconciliation in the two speeches, there are several points that worth discussing. In Obama's speech, the Self is moving to the Other, which can be seen in:

1.Minimization of the Self; to get closer to the Other

2.Praising of the Other; using the things native to the Other, whether in language or other techniques.

3.Acknowledging the debt to the Other

4.Admitting guilt and regret

5.Stressing common and mutual interests

6.Justifying the reasons of previous misunderstandings or enmities

\section{Promising}

In Sadat' speech, the Self also seeks to cut the distance to the Other through various strategies, all aiming at reconciliation with the Other. Of these are:

1.Approaching to the Other

2.Blaming the Other for previous actions

3.Stressing common grounds and aspects with the Other

4.Warning the Other of any previous acts 
5.Threatening the Other for any possible actions

The two speeches carry certain similar aspects that are common in both of them. In both speeches, the speakers demonstrate their own goals explicitly and sometimes openly. The goals are emphasized for the sake of showing interest in the Other, and therefore to reach reconciliation. That is why in both speeches, the speakers focus on the common aspects that both the Self and the Other have.

Both speakers used thanking, praising, acknowledging, and regretting in approaching the Other. However, there are certain aspects which are found in Sadat's speech but not found in Obama's speech, such as warning, threatening, and dictating actions or conditions. The identity of the speaker and the sort of the relationship between him and the other party justifies that sort of the rhetoric. Murphy (2010:2) says "Following extended periods of conflict or repression, political reconciliation is indispensable to the establishment or restoration of democratic relationships and critical to the pursuit of peacemaking globally".

In reconciliation, the party who has the power is often the one who initiates reconciliation, agreement and relation-building with the other. Here, the party who has the power is also the one who seeks reconciliation.

Sadat sought reconciliation and agreement with Israel following the war; Egypt won the war against Israel, and Obama sought reconciliation with Arabs out of power, assuming himself to be a representative of a powerful state. Hence, the authority and power of the speaker explains the position taken by him in the speech to the Other. This is also seen in the justification given by the Self as a pretext for approaching to the Other. Obama quotes aspects and things native and are attributed to the Other (Muslims and Arabs), such as the verses of the Holy Quran, the role of Al-Azhar, and the contributions of the Muslim civilizations.

On the other hand, Sadat reminds the Other (Israel) of the lessons of the war and the defeat on the ground, and he also uses things related to the Other by quoting verses of the Talmud, which is the tradition of the Jewish law and religion. Both presidents were able to assume the position they had when giving their speeches. Having been influential in their positions, both presidents succeeded in taking the attention of the Other, as well as controlling the setting of action. Both have succeeded in reaching reconciliation with the Other. The other aspect is the topic selection and structure. Both speakers put the topics they wanted. They also changed and controlled topics intended for discussion. Following van Dijk (2001:70), "recipients tend to accept beliefs, knowledge, and opinions through discourse from what they see as authoritative, trustworthy or credible sources."

Social power as well as mind control maintained by both speakers posed a considerable importance in the view of the audience, as the speakers used all the things that help them persuade the Other in their move. Schaap (2005:139) states that "Political reconciliation is initiated by conceiving the present as the moment from which a future community might understand itself to have originated. Political reconciliation is impelled by an anticipated remembrance that becomes available by constituting a space for politics within which conflicting memories and expectations can be brought to bear on each other".

\section{Conclusions}


The study attempts to demonstrate the action of reconciliation desired in the speeches of both presidents. The two speakers were successful in influencing the Other, and thus in attempting to reach reconciliation, though there are minor or few differences.

1.The consequences of these two reconciliation-aiming speeches are seen in the aftermath of these speeches; their effect on both the Self and Other can be realized in the consequent course of action. Following Sadat's speech, Israel's relation has been normalized with not only Egypt but also several other Arab countries. The United States relation with the Arab/Muslim world took a different turning represented in the pursuance of common interests, rather than resorting to enmity and prejudice.

2.The fact the Self succeeded in communicating his message to the Other proves that the Self was effective, eloquent, and persuasive

3.The two speeches are reconciliatory in form and content, as they contain all the elements of reconciliation, such as rapprochement, elimination of previous misconceptions, neutralization of any past conflicts or crises, and the like.

\section{Further Areas of Study}

1.A study can be conducted on reconciliation in the Iraqi political discourse. Reconciliation has been and is still the prominent topic widely deliberated whether by politicians or by the political circles in Iraq, considering the big changes happened in Iraq since 2003.

2.Reconciliation can be tracked in the speeches or statements of politicians or leaders in various areas in the world, particularly those areas with past conflicts or discords, for example in Former Yugoslavia, Russia-Ukraine, India-Pakistan conflict over disputed lands, US-Japan relations after world war II, South Africa after the abolition of the apartheid and many others.

3.The sociological as well as historical narratives underlying any reconciliation need to be investigated. For example, Turkey denies to have committed any massacre against the Armenians but Turkish officials have always expressly and implicitly sought reconciliation with Armenia in their speeches and statements to bypass any past or historical enmities.

4.Reconciliation can be investigated through other linguistic means or tools than critical discourse, such as pragmatics and conversational analysis.

5.There are other implications that worth researching in the two speeches discussed in this paper, such as repetition, promising, hedging, speech acts, and politeness.

\section{Implications}

1.Reconciliation was and is still a prominent theme not only in politics, but also in social, historical, and international aspects. Many nations, countries, and regions across the world suffer bilateral or multilateral unrest and instability, due to historical or previous conflicts and wars, which is reflected in the relations of these nations.

2.Political leaders in conflict- or war-stricken areas should do more to conclude reconciliation with the relevant parties. Such a move can be best accomplished by 
acknowledging the mistakes committed by those involved, holding accountable persons responsible for any wrong actions, and compensating the victims of such actions.

3.Reconciliation does not necessitate the forgiveness of those responsible of wrong actions at the cost of the victims or the sacrifices by certain people. It, hence, should be in agreement with justice or legal authority.

\section{Notes}

${ }^{[1]}$ Merriam-Webster Collegiate Dictionary

${ }^{[2]}$ The translation of Sadat's speech transcript is placed below the Arabic transcript.

\section{References}

\subsection{Primary Sources}

1.Obama's Speech

https://www.whitehouse.gov/the-press-office/remarks-president-cairo-university-6$\underline{04-09}$

\section{Sadat's Speech}

1. http://www.knesset.gov.il

2. http://www.zionism-israel.com

\subsection{Secondary Sources}

-Abdel-Noor, F. (2013). "Owning the Misdeeds of Japan's Wartime Regime" In Kwak, Jun-Hyeok and Melissa Nobles (eds.). Inherited Responsibility and Historical Reconciliation in East Asia. New York: Routledge, (23-37).

- Aguado, T. (2012). "Memory and Reconciliation in Spanish Society"

Dissidences: Hispanic Journal of Theory and Criticism, 4:8 (76-90).

- Basic, G. (2012). Reconciliation Narratives of Survivors from War in Bosnia and Herzegovina. Department of Sociology, Lund University, Sweden. File retrieved at http://www.soc.lu.se/en/goran-basic/publication/ 5470084 (Accessed December, 2015).

- Brown, P. and Levinson, S.C. (1987). Politeness: Some Universals in Language Use. Oxford: Oxford University Press.

- Burke, E. (1775/2015). Speech to Parliament on Reconciliation with the American Colonies. National Humanities Center. File Retrieved at http://www.americainclass.org/sources/makingrevolution/war/text1/ burkerecon speech.pdf (Accessed December, 2015).

- Burnet, J. (2008)."The Injustice of Local Justice: Truth, Reconciliation and Revenge in Rwanda" Genocide Studies and Prevention: An International Journal, 3:2 (173-193).

- Fairclough, N.L. (1989). Language and Power. London: Longman. 
- Hi, Y. (2009). The Search for Reconciliation: Sino-Japanese and GermanPolish Relations since World War II. New York and Cambridge, U.K.: Cambridge University Press.

- Merriam Webster Collegiate Dictionary. (MWCD). (2004).11 ${ }^{\text {th }}$ Edition. Mass: Springfield: Merriam-Webster Inc

- Murphy, C. (2010). A Moral Theory of Political Reconciliation. Cambridge: Cambridge University Press.

- Popovska, B. and Ristoska, Z. (2012)." Process of Reconciliation in a Postconflict Macedonia" Academicus: International Scientific Journal, 9(6376).

- Schaap, A. (2005). Political Reconciliation. London and New York: Routledge, Taylor and Francis Group.

- Škerlep, A. (2009). " The Rhetoric of Reconciliation in Post-Communist Slovenia: The Analysis of President Kuäœan's Speech in Koäœevskirog in July 1990" Teorija in Praksa, 46:6(839-856).

- Surenthiraraj, E. (2013).War during Reconciliation? A Study of Presidential Speeches on the Sri Lankan Ethnic Conflict Bridging War and Reconciliation. Master Thesis, Georgetown University.

- $\quad$ van Dijk, T.A. (2000)."Discourse, Ideology and Context". Folia Linguistica, $2(35-57)$.

- van Dijk, T.A. (2004)."Critical Discourse Analysis" In Deborah Schiffrin, Deborah Tannen, and Heidi E. Hamilton, (Eds.). The Handbook of Discourse Analysis. New York: Blackwell, (252-371).

- Wodak, R. and Meyer, M. (Eds.) (2001). Methods of Critical Discourse Analysis. London: Sage. 